Studies in Higher Education

ISSN: 0307-5079 (Print) 1470-174X (Online) Journal homepage: https://www.tandfonline.com/loi/cshe20

\title{
Critical thinking in business education: current outlook and future prospects
}

\section{Angelito Calma \& Martin Davies}

To cite this article: Angelito Calma \& Martin Davies (2020): Critical thinking in business education: current outlook and future prospects, Studies in Higher Education, DOI: 10.1080/03075079.2020.1716324

To link to this article: https://doi.org/10.1080/03075079.2020.1716324

曲 Published online: 06 Feb 2020.

Submit your article to this journal $₫$

Џ Article views: 125

Q View related articles $\widetilde{ }$

View Crossmark data 


\title{
Critical thinking in business education: current outlook and future prospects
}

\author{
Angelito Calma (D) and Martin Davies $\mathbb{D}^{\mathrm{b}}$ \\ ${ }^{\mathrm{a}}$ Faculty of Business and Economics, University of Melbourne, Carlton, Australia; ${ }^{\mathrm{b}}$ Melbourne Graduate School of \\ Education, University of Melbourne, Carlton, Australia
}

\begin{abstract}
This study investigates all available literature related to critical thinking in business education in a survey of publications in the field produced from 1990-2019. It conducts a thematic analysis of 787 articles found in Web of Science and Google Scholar, including a specific focus on 55 highly-cited articles. The aim is to investigate the importance of critical thinking in business education, how it is conceptualised in business education research, the business contexts in which critical thinking is situated, and the key and more marginal themes related to critical thinking outlined in the business and business education literature. The paper outlines six key areas and topics associated with those areas. It suggests future directions for further scholarly work in the area of critical thinking in business education.
\end{abstract}

\section{KEYWORDS}

Critical thinking; business; business education; higherorder skills; systematic review; literature review

\section{Introduction}

Critical thinking is an increasingly important skill needed in a changing, challenging world replete with 'fake news' (Khidhir 2018). It is seen as an important part of a repertoire of skills that students require in both academic and professional domains. This includes being successful in business in an increasingly globalised economy (Kirby 2004). A 2016 report claims that demand for critical thinking skills has risen 158 percent (Foundation for Young Australians 2016). Surveys by Forbes using data from CareerBuilder and $\mathrm{O}^{*} \mathrm{Net}$ - the US clearinghouse of occupational information-identified critical thinking as the first-listed in a list of top ten skills that help people get hired. In a major 2006 report, a consortium of US organisations surveyed ranked 'critical thinking' higher than 'innovation' and 'application of information technology' as a skill (Casner-Lotto and Benner 2006). Other documents that call for the importance of critical thinking skills include the National Association of Colleges and Employers' 2018 Job Outlook (NACE 2019) survey, the Foundation for Young Australians' report (FYA 2017), The New Work Smarts: Thriving in the New Work Order 2017 report, and the Organisation for Economic Co-operation and Development's document entitled Future of Education and Skills 2030 (OECD 2019) . NACE consistently placed 'critical thinking' as a key competency for career readiness. In 2030, FYA estimates that employees will spend $41 \%$ more time at work on critical thinking and judgment, while the OECD predicts that critical thinking is necessary for learning how to create new value, reconcile tensions and dilemmas, and take responsibility. A recent study by Sellars and colleagues (2018) also reaffirms the value of critical thinking as the leading twenty-first century skill for success in education, life and work.

CONTACT Angelito Calma calmaa@unimelb.edu.au E Faculty of Business and Economics, University of Melbourne, Carlton, Australia 
Professional associations in the business sector - such as CPA Australia (the professional body in Accounting) - add support to this by drawing attention to the kind of skills that graduates need to obtain that go beyond skills based solely on content memorisation (Wilkin 2017). Chief among these is the skill of critical thinking. The Association to Advance Collegiate Schools of Business, the largest business school accreditation body, highlights the importance of critical thinking and analytical skills as crucial areas of curriculum content in business disciplines (AACSB 2018). A cursory look at various programmes and subjects (including units of study) across many institutions around the world indicates that critical thinking is embedded in discipline-specific outcomes as a desirable generic or transferable capability in graduating students. Examples can be found in many business masters programmes in the US, Canada, the UK and Australia. Stanford's Graduate School of Business, for example, puts critical thinking at the centre of its MBA programme (lqbal 2019). The London Business School's Masters of Financial Analysis likewise places significant importance on critical thinking in personal and professional development (London Business School 2019).

Critical thinking is particularly vital to business as a practitioner discipline. Just as effective critical thinking helps a health care professional make important decisions to save lives, or assists lawyers in making decisions in the interests of clients, so too critical thinking impacts on how a business practitioner makes strategic investment decisions for optimising clients' returns. How such skills are developed in the business curriculum is a key determinant in how and whether such skills are inculcated in business graduates. Rote learning that relies on imparting facts to students (Celuch and Slama 1999; Diaz-Lefebvre 2004) is clearly secondary to educational strategies that foster analytical capacities that trigger the use of high order thinking skills (Snyder and Snyder 2008; Wong 2007). How is this best done? What does the literature say about the development of critical thinking skills in business disciplines? This paper sets itself the task of finding out. This paper uses data analysis software to establish a summary of the literature based on themes and areas of research using a data source of more than 700 business-related articles.

\section{What is critical thinking?}

Critical thinking has been described as a type of high-order thinking (HOT) that involves controlled and measured thinking processes. This can be distinguished from forms of low-order thinking, and mere attention and perceptions (Smith 2003). With some reservations, critical thinking can be said to occupy the top three levels - analysis, synthesis and evaluation-of Bloom's celebrated taxonomy of educational objectives (Bloom 1964; Ennis 1987). In recent decades, critical thinking has developed a sizable literature and a plethora of definitions can be discerned among experts in the field. In particular, critical thinking is said to be:

- ' ... the correct assessing of statements' (Ennis 1962, 8);

- ' ... the propensity and skill to engage in an activity of reflective skepticism' (McPeck 1981, 8);

- ... 'the intelligent use of all available evidence for the solution of some problem' (McPeck 1981, 12);

- ' ... reflective and reasonable thinking that is focused on deciding what to believe or do' (Ennis 1985, 45);

- ' ... the ability to analyze facts, generate and organize ideas, defend opinions, make comparisons, draw inferences, evaluate arguments and solve problems' (Chance 1986, 6);

- '. ... [a skill] to detect and avoid fallacious reasoning and to analyze deductive and inductive arguments' (Kurfiss 1988, iii);

- 'an active, systematic process of understanding and evaluating arguments' (Mayer and Goodchild 1990, 4);

- ' ... careful and deliberate determination of whether to accept, reject, or suspend judgment' (Moore and Parker 1991, 4); and

- ' ... thinking about your thinking while you're thinking to make your thinking better' (Paul 1993, 91). 
Possibly the most often cited definition in the literature is of critical thinking as 'reasonable reflective thinking focused on deciding what to believe or do' (Ennis 1996, xvii). Each of the words in Ennis' definition is deliberately chosen and necessary: thinking must be reasonable to be critical thinking (it can't be pointless, absurd, or random); it must be reflective (not superficial or accidental); likewise, it must give us pause in our decision-making (we must be prepared to base our judgements on it). Finally, we must be prepared to do something as a result of this considered intelligence, i.e. act accordingly (it would not be critical thinking if it meant we were practically impotent; that is, we analysed something critically and could not do anything about it). It may be that we don't always act, but we sometimes do; hence believe or do. A variety of other definitions and approaches to the importance of critical thinking are outlined in a recently published handbook (Davies and Barnett 2015).

Attempts to define critical thinking point towards controlled reflective thought that utilises active argumentation, logical reasoning, inferencing and appraisal of information in making value judgements (Behar-Horenstein and Niu 2011; Shakirova 2007; Smith 2003; Snyder and Snyder 2008). Halpern (2007), for example, views critical thinking as:

the use of those cognitive skills or strategies that increase the probability of a desirable outcome. It is used to describe thinking that is purposeful, reasoned, and goal directed - the kind of thinking involved in solving problems, formulating inferences, calculating likelihoods, and making decisions, when the thinker is using skills that are thoughtful and effective for the particular context and type of thinking task. (6)

In the 1980s the American Philosophical Association convened an authoritative panel of forty-six noted experts on the subject, to produce a definitive account of the concept. Each of these were professionals noted for their authoritative contributions to the field and the process involved six rounds of questions over a period of nearly two years (February 1988-November 1989). It resulted in the production of the landmark Delphi Report (Facione 1990). This led to the following definition of critical thinking; a definition which is as long and comprehensive as it is dense and hard to follow:

\footnotetext{
We understand critical thinking to be purposeful, self-regulatory judgment which results in interpretation, analysis, evaluation and inference as well as explanation of the evidential conceptual, methodological, criteriological or contextual considerations upon which that judgment was based. Critical thinking is essential as a tool of inquiry. Critical thinking is a pervasive and self-rectifying, human phenomenon. The ideal critical thinker is habitually inquisitive, well-informed, honest in facing personal biases, prudent in making judgments, willing to consider, clear about issues, orderly in complex matters, diligent in seeking relevant information, reasonable in selection of criteria, focused in inquiry and persistent in seeking results which are as precise as the subject and circumstances of inquiry permit. (Facione 1990, 3)
}

It might be noticed that the first half of this definition defines the skills needed by a critical thinker, and the second half outlines the kind of attitudinal attributes the critical thinker possesses. This distinction is vital. Critical thinking requires both skills and dispositions (Facione 1990). The aforementioned skills need to be supplemented by a willingness or disposition to exercise them. Just as it is possible for a pianist to be talented but with no disposition to exercise their talent, so a person can have skills in critical thinking but be disinclined to follow through with them. Educational programmes devoted to fostering critical thinking clearly have to encourage both. This is important, one might assume, for graduates of business disciplines. Critical thinking dispositions include open-mindedness, inquisitiveness, respect, self-efficacy, attentiveness, intrinsic goal orientation, perseverance, organisation, truth-seeking, creativity, scepticism, reflection and resourcefulness (Bailin 2002; Ennis 1989; Facione 1990; Halpern 1999).

\section{Critical thinking in business education}

To date the philosophical literature on critical thinking has been focussed predominantly on exploring definitions and distinguishing between issues such as whether critical thinking is 'generic' (universal for all disciplines) or 'specific' to the contexts in which it is used (for a flavour of this debate, see Davies 2006; Davies 2013; Moore 2004, 2011). However, despite early appearances in the 
1920s, and surge of interest from the 1970s (Google Ngram Viewer 2019), critical thinking is still relatively underexplored in business education. The aim of the article is to review the literature on critical thinking and its application in business education. To this end we summarise the areas of research interest relevant to critical thinking in business, identify the research gaps, and suggest directions for future research. The aim is to map the extent of critical thinking in business education literature. To the extent that this has not been done before, this constitutes a contribution to the field.

Critical thinking in business education is an under-researched area. There are disproportionately more articles on critical thinking in the medical, nursing and allied health studies than in business (for examples, see Chan 2018; Reale et al. 2018). This would indicate the importance of critical thinking in medical education in terms of its importance for health care diagnostics and overcoming management problems. Both improve medical practitioners' diagnostic and other professional skills (Zayapragassarazan et al. 2016). The importance of critical thinking in other disciplines such as politics (Beasley and Cao 2014), psychology (Griggs et al. 1998), architecture (Richards 2018), disaster management (Albanese and Paturas 2018), does not go unnoticed. The extent to which business education regards critical thinking to be a relevant area of study needs to be similarly determined.

In this paper, we pose the following research questions in relation to the existing literature in the field:

(1) How important is critical thinking in business education? (RQ1)

(2) How is critical thinking conceptualised in business education research? (RQ2)

(3) In which business contexts is critical thinking situated? (RQ3)

(4) Which topic areas in critical thinking are neglected in research on critical thinking in business education? (RQ4)

In this paper, we conduct a citation and NVivo analysis of over 700 articles in the area of critical thinking in business education. Of these papers, we focus on the 55 most cited articles for further more detailed analysis. We attempt to ascertain which have made a significant impact on the growth of the literature based on their popularity as cited sources.

\section{Method}

\section{Data collection}

A literature search was conducted over the period from 1990-2019 using Web of Science. It involved three separate stages: Stage 1 required a search of the literature related to critical thinking in the domain of general business education. Stage 2 involved a search for critical thinking in specific business education domains (e.g. accounting, marketing, economics, management, human resource management, supply chain management, international business, MBAs, entrepreneurship). Stage 3 required a synonym search (e.g. 'problem solving', 'deep learning'). By including peer-reviewed articles only (i.e. excluding editorial notes, conference proceedings, opinion pieces, etc), and using targeted search terms and phrases such as 'critical thinking business education', 'critical thinking + business', 'critical thinking + marketing education', a total of 1,239 articles were found during the period under investigation. Of these, a total of 470 duplicates were found and removed, leaving 769 articles as usable data. A more refined search amongst the 769 articles allowed us to focus on papers with more than 50 citations. This identified 37 highly cited articles.

We then used Google Scholar to search for other articles that might have been overlooked in the initial search phase in Stage 2. Another 18 articles with 50 or more citations were found. Combining these with the 37 papers found previously, 55 articles were considered as usable data. By examining the most cited articles, our analysis was limited to articles that have made a significant contribution to the literature on critical thinking in business education. 
Thus, we used two sets of data: (1) the 55 most cited articles; and (2) the 787 'all articles' (769 from Web of Science and 18 from Google Scholar).

\section{Data analysis}

The method of data analysis was in two parts. Part 1 involved coding and categorising each of the 55 articles deductively. The deductive method of coding was more appropriate for this study because categories were developed beforehand. The deductive process involved a pre-determined list of codes. Data was first collected using these codes and then the categories were organised and re-organised to reflect the structure of the data. The overall intention was to code articles based on a number of categories as listed in the research questions earlier: i.e. those that discuss (1) the importance of critical thinking in business education (RQ1); (2) how the concept of 'critical thinking' is understood in business (RQ2); (3) in which contexts critical thinking studies are situated (RQ3); and (4) the research gaps articulated in each of the articles under consideration (RQ4). This categorisation of codes reflects the themes presented later in the Results section.

Part 2 analysed the 700+ articles using NVivo. NVivo is a qualitative data analysis software used for thematic analysis (QSR International 2019). While less specific than the 55 articles, all 787 articlesi.e.769 in the initial search and 18 from the follow-up search-were filtered by the terms 'business education', 'teaching and learning in business' or by 'critical thinking' as applied in various business fields such as accounting, economics, finance, management and marketing. This second analysis was performed to provide support to the earlier themes identified in the deductive analysis. NVivo coding only uses titles, keywords and abstracts. However, unlike manual coding in Part 1, Part 2 coding using NVivo focused on making meaning through certain terms that appear within titles, keywords and abstracts. The focus here was on the analysis of themes that gather the strongest references (i.e. the number of times a particular code appears in titles, abstracts and keywords). Particular attention is given to the underlying theoretical foundations, methods or approaches used, as well as disciplinary contexts and associated critical thinking skills of most interest to researchers. NVivo provides considerable advantages when dealing with a large dataset as it allows effective data management and organisation of data into themes, quicker data retrieval, and sophisticated content analysis of word strings.

In sum, the two analyses - a narrow deductive analysis and a broader NVivo-based analysisprovide an attempt at a comprehensive contextual understanding of the depth of research in the emerging field of critical thinking in business education.

\section{Results}

Presentation of the results below begins with the findings from Part 1 of the analysis followed by Part 2 of the analysis. Part 1 presentation follows the themes in the categories mentioned earlier (i.e. RQ1, RQ2 and so on). At the end of Part 1, we provide a summary of the key findings from Part 1 of the analysis. The Part 2 presentation focuses on the theories, models or approaches used as well as the research contexts. However, before we discuss this, preliminary findings using the metadata available from the 769 articles from Web of Science is presented. This provides key information in understanding the data.

First, we looked at the author keywords. Author keywords indicate the topics attached to the articles from the authors themselves when they submit the articles for publication. We found 2,971 keywords in the dataset under consideration. Other than the most obviously popular keyword, critical thinking (65 times), we also found education (28), higher education (24), experiential learning (21) and learning (18). The other most popular keywords were management education and ethics (16 times each), pedagogy and sustainability (15 each) and, lastly, gender (13). These are the top 10 author keywords used across the 769 articles from Web of Science from 1990 to 2019. 
Second, we looked at where articles on critical thinking in business education were published. Analysis of the data indicates the most popular journal is the Journal of Business Ethics (73 articles), followed by Management Learning (25), Systems Research and Behavioral Science (19), Academy of Management Learning and Education (16) and Advances in Accounting Education: Teaching and Curriculum Innovations (13). Using the Australian Business Dean's Council (ABDC) journal rankings as a proxy for the quality of the journal, where $A$ and $A^{*}$ are top ratings, all are ranked ' $A$ ' except for Advances in Accounting Education (B rating). This indicates the relative quality of the articles based on a reputable list of journal quality.

The following section details the results from Part 1 of the analysis.

\section{The importance of critical thinking in business education (RQ1)}

It is appropriate to start the results section with studies that discuss the importance of critical thinking in business education. This would indicate how critical thinking is embedded in business education in terms of its application to curriculum documents, subject guides and course materials. The literature outlines critical thinking as an important part of a set of skills that need to be embedded in business education. To think critically and to learn critically is often seen as an important skill every business student should have. Instructors and students are encouraged to look at critical thinking as part of discipline-specific learning outcomes and its use is as a 'thinking tool' when confronted with issues in business that require solutions. For example, Celuch and Slama (1999) believe that a number of valuable traits are developed in the business student when critical thinking is embedded in the course, such as intellectual humility, intellectual courage, intellectual empathy, intellectual integrity, intellectual perseverance, intellectual faith in reason, and intellectual fair-mindedness. Springer and Borthick (2004) also believe that 'the ability to think critically, reason in a variety of ways, and solve ill-structured problems has become essential in a world in which the premium is on one's ability to develop an acceptable solution to the next new problem' (277).

However, Bonk and Smith (1998) claim that critical thinking should not be simply considered as a thinking tool (e.g. as a type of higher-order thinking skill) without examining the experiences and the environments that can better foster it. They suggest that learning environments should be changed to suit the workplaces of the twenty-first century to develop both creative and critical thinking skills, i.e. a more practice-orientated aim. Others claim that critical thinking has a more applied focus too, e.g. some suggest that it can be used for peer learning (Borthick and Schneider 2016; Carr et al. 2018; Dehler, Welsh, and Lewis 2001) or for promoting lifelong learning (Celuch and Slama 1999).

From this brief account of the purpose of critical thinking from the business education literature, it would seem that the stated purpose has shifted from an assumed, rather generalised and amorphous benefit, to it having a more pragmatic focus in terms of addressing real-world issues and concerns (Bejinaru 2018; Mingers 2000). Recent examples from the business literature emphasise that business education should incorporate critical thinking to improve managerial practices (Bloch and Spataro 2014), students' employability (Carr et al. 2018), or resolving tensions between theory and practice (Bell and Loon 2015; Dyck 2017). Further, critical thinking in business education has been seen as being useful as a lens with which to discuss business ethics in the classroom, and in promoting discussions around managing tensions between business and the public interest (Garcia 2009). More recently, the business literature has associated 'critical thinking' with ethical thinking and judgements, or moral misconduct in business (Hummel, Pfaff, and Rost 2018). From the literature surveyed, the perceived focus of critical thinking in business education appears to be becoming more narrowlyfocussed and pragmatic in scope.

\section{Conceptions of critical thinking in business education (RQ2)}

In terms of its relationship to business education practice, the literature surveyed shows that critical thinking is usually understood as a skill set that can be acquired through appropriate teaching 
strategies, curriculum design and student engagement (Alavi, Wheeler, and Valacich 1995; Snyder and Snyder 2008; Zabit 2010). It is mostly associated with managerial and business-related capabilities such as strategic thinking (Casey and Goldman 2010), leadership (Garcia 2009) and decisionmaking (Quigley 2013). These are specific business competencies that characterise critical thinking as applied in business settings. More recently, however, it has been associated with entrepreneurship (Deale 2016; Verzat, O'Shea, and Jore 2017), creativity and innovation (Sharma and Sharma 2018; von der Heidt 2018).

While there are established philosophical definitions of critical thinking, such as those mentioned in the introduction earlier, definitions of critical thinking in the business context are less clear. While many business scholars mention its importance, they are less concerned about defining precisely what it is. This is probably due to the complexity of isolating a definition of critical thinking amongst its many associated sub-skills, its relational status with other higher-order skills, or its conception as an anchor term for related skills. For example, it was found in the business literature that critical thinking is often not studied directly, but along with other skills like communication, perspective-taking and the ability to collaborate in business situations (Griffith 1999). Unlike the philosophical literature, which attempts to investigate critical thinking in isolation, the business literature unsurprisingly assesses it in respect of its business-related applications. This suggests that business scholars are less interested in critical thinking as a concept, as much as what it can do for business practices.

As an anchor term for business-related applications, it is typically considered as a general construct linked to theoretical constructs such as constructivism, leadership and education, or defined broadly as thinking deeply about complex business-related matters (Flores et al. 2012). Part of the challenge in defining critical thinking (in the context of, or for the purposes of, business education) is that some theorists in the area believe that it is highly dependent on the specific business-related disciplines in which it is practised (Cunningham 2014) and that it is understood and practised differently across different business cultures (Turner 2005). The area of 'culture' and its impact on critical thinking is generally not discussed a great deal in the philosophical literature as critical thinking is generally seen as a western notion descending from the development of informal logic (although see Ennis (1998), see also section IV, Davies and Barnett 2015).

\section{Situational contexts of critical thinking in business education (RQ3)}

When researchers from business disciplines investigate critical thinking, they do so by suggesting an environment where students learn a variety of business-related skills such as problem solving, leadership, decision making, debating and an orientation towards service and experiential learning. This, however, complicates any clear understanding of critical thinking in business disciplines because it is not researched directly and in isolation from surrounding concepts. Instead of explicitly suggesting how critical thinking is fostered, the business research intimates that this occurs indirectly by proposing conditions that develop other skills that, in turn, develop critical thinking skills. This muddies the waters considerably. It is tantamount to subordinating the concept of critical thinking to concepts with which they claim it is associated, for example, and most commonly, 'problem solving'. 'Critical thinking' does have established definitions. However, the business literature seems to ignore these, or be unaware of them.

It is often assumed, for example, that critical thinking and problem solving are identical skills. However, this is not the case. Essentially critical thinking are habits of mind that allow, and provide an intellectual framework, for problem solving to occur. All critical thinking can be seen in relation to 'problems' of various kinds, so critical thinking and problem solving are often (and naturally) seen as synonyms. This is especially so as many problems requiring solutions also require rational, reflective thinking (e.g. political, social, environmental, and some business problems). Conflation of these concepts is therefore common, especially in the business education context. However, the relationship between the concepts is asymmetric. Not all problem solving requires critical thinking (a manual task, e.g. undoing a nut sometimes requires only brute strength, and many problems 
merely require rote thinking, e.g. solving a mathematical equation). Sometimes problem solving requires thinking skills, e.g. how best to use a wrench, but not critical thinking skills qua rational, reflective thinking. Some problems, for example, require emotional intelligence; i.e. thinking that is not necessarily rational nor reflective. So while critical thinking is often mentioned in relation to problem solving, not all problem solving requires critical thinking.

Thus far, we have established that the relationship between critical thinking and other skills and capabilities is frequently examined in the business literature. To be precise, the different skills associated with critical thinking tend to promote the development of the business student as a holistic and well-rounded individual who is able to take on leadership and make effective decisions (Maclagan 2012; Quigley 2013) supported by moral reasoning (Christensen, Cote, and Latham 2016) and entrepreneurial qualities (Deale 2016; Rezaei, Dana, and Ramadani 2017; Verzat, O'Shea, and Jore 2017; Wright, Paroutis, and Blettner 2013). However, teasing out the role that these very different concepts play in achieving a 'critical business thinker' mindset is seldom addressed in detail.

\section{Neglected topics and research gaps (RQ4)}

The view that critical thinking is an anchor term for thinking deeply and about complex businessrelation concerns is clearly an important one in the business education literature. There is also a recurring theme in the literature about seeing critical thinking in terms of its relationship with other skills and thinking approaches (i.e. problem-solving, leadership, creativity, collaboration, and so forth). This theme is not always made explicit in the literature and the role and relationship between these very different concepts are seldom distinguished clearly. Third, there is a perceived need to review the use and importance of critical thinking in the business domain specifically, and higher education more broadly (Allison 2019; Latif et al. 2019). Fourth, there is an emphasis on the importance of critical thinking as it may vary across cultures. Fifth, a recurring theme is that there is limited research on improving our understanding of critical thinking in business learning and practices. Sixth, and as a corollary to the latter, existing business education research lacks suggestions on how to teach it.

However, more importantly, there is very limited literature on the assessment and measurement of critical thinking in business education contexts (Bandyopadhyay and Szostek 2019; Page and Mukherjee 2007; Peach, Mukherjee, and Hornyak 2007; Sormunen and Chalupa 1994). There are calls to gather empirical evidence to assess students' learning of critical thinking (Wolcott et al. 2002). This is despite the fact that little work has been done in business contexts on how to define it.

Finally, thinking critically about ethical issues is a growing body of research (particularly in relation to business misconduct, environmental issues, corporate social responsibility). A number of authors have suggested that this skill should be part of the contemporary business students' skill-set (Ermasova, Wagner, and Nguyen 2017; Hummel, Pfaff, and Rost 2018; Maclagan and Campbell 2011; McWilliams and Nahavandi 2006).

\section{Summary of the literature}

In addition to answering the research questions we set out at the beginning of this paper, we also summarised the literature on critical thinking in business education into six main areas. Examples of key topics are presented under each of those areas Table 1.

In relation to the above, we find one important area of growing interest in the study of critical thinking in business education and one important dilemma. We reiterate here that a growing interest is in business ethics. This probably stems from pressure for businesses to engage in fair practices and competition and a greater sense of responsibility and accountability to customers, stakeholders and the society. Thus, more visibly, critical thinking is seen as a way for students to learn to navigate ethical issues in increasingly complex business environments (Hummel, Pfaff, and Rost 2018; Maclagan and Campbell 2011). 
Table 1. Summary of research in critical thinking in business education.

\begin{tabular}{|c|c|}
\hline Area & Key topics \\
\hline $\begin{array}{l}\text { 1. The importance of critical } \\
\text { thinking in business } \\
\text { education }\end{array}$ & $\begin{array}{l}\text { - Critical thinking as a useful skill to embed in } \\
\text { teaching and learning } \\
\text { - Critical thinking can address real-world } \\
\text { issues }\end{array}$ \\
\hline $\begin{array}{l}\text { 2. The importance of critical } \\
\text { thinking in managerial and } \\
\text { business-related capabilities }\end{array}$ & $\begin{array}{l}\text { - Importance of strategic thinking for } \\
\text { business managers and leaders } \\
\text { - Importance of critical thinking in leadership } \\
\text { and decision making } \\
\text { - Critical thinking and proactive attitude as } \\
\text { important elements in the entrepreneurial } \\
\text { mindset } \\
\text { - To improve students' ethical reasoning }\end{array}$ \\
\hline
\end{tabular}

3. Beliefs and approaches to teaching critical thinking in business education
4. Fostering critical thinking in teaching and learning
- Rote learning does not help advance critical thinking skills

- Strategies that use high order thinking skills are more effective

- Teaching critical thinking combined with discipline-specific knowledge

- Teaching critical thinking separately as a subset of skills

- Mixed approach to teaching critical thinking (combining both general and subject-specific knowledge)

- Student-centred consultative teaching style where teachers work with students to build their thinking skills

- Student-centred experiential learning where theory and practice are combined

- Problem-based learning strategies

- Use of questioning techniques to analyse, synthesise and evaluate information

- Debate-based approach where debating procedures and formats are adapted to the curriculum

- Consulting projects where students analyse data to solve problems

- Active learning strategies to encourage critical thinking

- Collaborative learning environments have a positive influence in developing critical thinking

- Students' ethnocultural origin plays an important role

5. Methods for critical thinking assessment

- Empirically validated instruments to measure the ability to think critically (e.g. California Critical Thinking Dispositions Inventory)

- Bloom's Taxonomy as a framework

- Student perception surveys

- Developing critical thinking as a skill

6. Current emphasis of studies on critical thinking in business education

\section{- Application of critical thinking in various} business fields
Proponents

Bonk and Smith 1998; Carr et al. 2018; Casey and Goldman 2010; Celuch and Slama 1999; Dehler, Welsh, and Lewis 2001; Garcia 2009; Hummel, Pfaff, and Rost 2018; Springer and Borthick 2004;

Bloch and Spataro 2014; Casey and Goldman 2010; Deale 2016; Garcia 2009; Quigley 2013; Sharma and Sharma 2018; Verzat, O'Shea, and Jore 2017; von der Heidt 2018

Bailin 2002; Celuch and Slama 1999; DiazLefebvre 2004; Ennis 1989; Facione 1990; Halpern 2001; McPeck 1990; Snyder and Snyder 2008; Gelder 2005; Wong 2007; Willingham 2008

Alavi, Wheeler, and Valacich 1995; Borg and Stranahan 2010; Brook and Milner 2014; Eggers, Lovelace, and Kraft 2017; Lee et al. 2016; Levant, Coulmont, and Sandu 2016; Prince 2004

Butler et al. 2012; Cloete 2018; D'Alessio, Avolio, and Charles 2020; Dwyer, Hogan, and Stewart 2014; Facione 1990; Halpern 1998; Nentl and Zietlow 2008; Reeves 1990; Seldomridge and Walsh 2006; Watson and Glaser 1994; Wilkin 2017

Alavi, Wheeler, and Valacich 1995; Ayad 2010; Bonk and Smith 1998; Casey and Goldman 2010; Christensen, Cote, and Latham 2016; Deale 2016; Ermasova, Wagner, and 
Table 1. Continued.

\begin{tabular}{|c|c|c|}
\hline Area & Key topics & Proponents \\
\hline & $\begin{array}{l}\text { - Application of critical thinking in } \\
\text { professional practice }\end{array}$ & $\begin{array}{l}\text { Nguyen 2017; Glen, Sucio, and Baughn } \\
\text { 2014; Griffith 1999; Hummel, Pfaff, and Rost } \\
\text { 2018; Johansson-Sköldberg, Woodilla, and } \\
\text { Çetinkaya 2013; Lamb 2015; Maclagan } \\
\text { 2012; Maclagan and Campbell 2011; } \\
\text { McWilliams and Nahavandi 2006; McEwen } \\
\text { 1994; Mingers 2015; Roy and Macchiette } \\
\text { 2005; Quigley 2013; Rezaei, Dana, and } \\
\text { Ramadani 2017; Snyder and Snyder 2008; } \\
\text { Verzat, O'Shea, and Jore 2017; Wolcott et al. } \\
\text { 2002; Wright, Paroutis, and Blettner 2013; } \\
\text { Zabit 2010 }\end{array}$ \\
\hline
\end{tabular}

The dilemma is that while there is general consensus that critical thinking can be effectively taught and learnt, how to do this is generally unclear. A number of approaches have been suggested but the literature has yet to find evidence of their effectiveness. For example, some believe that it should be included in problem-based learning (Zabit 2010) or debate based learning activities. Others see critical thinking as an important component in design thinking (Glen, Sucio, and Baughn 2014; Johansson-Sköldberg, Woodilla, and Çetinkaya 2013) or experiential learning (Lamb 2015).

The following section details Part 2 of the analysis.

NVivo was used to analyse the 787 articles. We extend the analysis in Part 1 to pay particular attention to the underlying theoretical foundations, methods or approaches used, disciplinary contexts, and associated skills of most interest to researchers.

\section{Theoretical foundations}

There were 160 references to 'theory' as a code or theme. Closer inspection reveals the theories most used by researchers of critical thinking in business education. Learning theory (12 references) was used as a theoretical foundation the most, followed by social theory and critical theory (10 each). Discipline-based theories such as marketing, ethics, management, game and critical race theories follow. In some cases the term 'theory' or 'theories' have only been applied once or twice, or sporadically, and have uneven application in the literature.

\section{Models and methods used}

A number of different models and methods have been used to analyse critical thinking according to our analysis but none is more strikingly prominent than the others. In most use is theoretical models but only with 11 references, followed by structural equation modelling, learning, systemic and experiential learning models, as with less than 10 references. However, as mentioned earlier, there is very little empirical research using quantitative techniques compared to conceptual models or methods used. The literature is bereft in terms of offering empirical approaches to the topic of critical thinking as it applies in business contexts. This is an area of great neglect.

\section{Study contexts}

Naturally, business students are the subjects of studies that involve the participation of students. There were 33 references to business students; seven to business graduates and five to undergraduate business students. The most investigated topic in these contexts is ethics: business ethics (20), business ethics education including teaching business ethics (20). The specific contexts in business focus on 
business simulation (7), business process (6), business practices (5), business leaders and managers (10) and business situations or issues (4).

\section{Disciplinary contexts}

As expected, the embedding of critical thinking has been most apparent in management (47 references) and business (35) pedagogy. The next most apparent themes relate to studies pertaining to entrepreneurship (24), marketing (22), ethics (20), accounting (19), business ethics (14) and economics (10).

\section{Learning environments}

Critical thinking in business education, when studied, often is attached to understanding the learning environment (33 references), learning outcomes (30), the learning process (30), experiential learning (28) and the learning experience (24). It is also most associated with learning strategies (12), collaborative learning (11) and lifelong learning (10).

\section{Associated skills}

Other than critical thinking skills, the focus of the research thus far has been on investigations around communication skills (15 references), soft skills and thinking skills (13 references each). This is followed by other related skills such as entrepreneurial skills and interpersonal skills (9 each) and technical skills (7). The results also indicate a number of management- or business-related skills such as negotiation, problem solving, management, leadership, collaboration, reflection, written communication and presentation skills (3-5 references).

\section{A special focus on ethics and moral reasoning}

We noted earlier that business ethics plays a more prominent role in the teaching and learning of critical thinking in business education. A closer look at what constitutes this is to examine the subthemes under the broad field of ethics. Results show that the literature in business concerns itself mostly with ethical judgment (30 references), ethical decision-making or ethical decisions (18), ethical issues (16), ethical dilemmas (14), ethical behaviour (12) and ethical sensitivity (10). With regards to morality, the studies analysed are most associated with moral reasoning (22 references), moral development (21) and moral judgment(16).

\section{Discussion}

According to our analysis, other than the themes identified above, research into critical thinking in business education exhibits no particular focus area, nor dominant domain of research investigation. This is ironic given that critical thinking is considered to be necessary for business education. On the other hand, the nature of 'critical thinking' is something with which even experts in the field disagree, so it is unsurprising business academics have not to date tackled the subject head-on. Nonetheless, even a working definition of what critical thinking in business might constitute would, we feel, be useful to advance research in the area as it relates to business disciplines. But, as we have seen, this has not been forthcoming in the business literature to date. A focus on how to teach, learn and assess critical thinking would also be welcomed. A definition of critical thinking as used in business is, naturally, preparatory to an understanding of how to best teach it. Current investigations in the literature relate, as we have seen, to the importance of critical thinking as a skill and how to apply it in business practice. But without a definition of critical thinking, it is unclear how one is supposed to know if one has successfully acquired it. The urgency of this can also be seen from the 
students' perspective. In the development of critical thinking as a skill, part of the problem lies in students' failure to grasp what 'critical thinking' means despite its perceived value to them (Beasley and Cao 2014).

Critical thinking is comprised not just of skills but also of dispositions. Current research in the area of critical thinking business education does not appear to acknowledge this basic, but necessary, distinction. An investigation into the dispositions considered most useful and appropriate in business contexts, and how they are fostered in the classroom, is needed. For example, there are a number of intellectual dispositions (e.g. open-mindedness with regard to divergent views, seeking and offering reasons, diligence in seeking relevant information) and emotional dispositions (e.g. discrepancy-seeking attitude, mindfulness, inquisitiveness, maturity, preparedness to participate in community, tolerance of ambiguity). These dispositions are prima facie among the important ones that business students should develop. Investigations on these, and which are the most important, are currently missing in the business education literature. In future work, we aim to correct this oversight (for a complete taxonomy of dispositions covering 40 years of discussion on this topic, see Davies and Calma, paper in progress).

Critical thinking is confused with, or considered in relation to, other skills such as problem solving. In some situations, it is often linked vaguely to areas such as collaboration, creativity and leadership. While critical thinking is associated with these skills, it is not clear whether the instruments used are, in fact, measuring critical thinking. Critical thinking is also often measured using instruments or scales developed such as the Critical Thinking Dispositions Scale (CTDS) or the California Critical Thinking Dispositions Inventory (CCTDI). Studies on the applications of these measurement tools to the development of critical thinking skills and dispositions in business contexts are absent. This too is a potentially promising area of future study.

Factors leading to critical thinking skill development clearly needs further investigation in the context of business education. Comparisons between skill development in various disciplines in business (e.g. accounting, economics, management, marketing and finance) might be illuminating. For example, an exploration of how critical thinking is fostered among accounting students, against how it is fostered among marketing students, would be useful. Do students in certain subdisciplinary areas of business exhibit greater critical thinking skills compared to other areas? Do they exhibit improved critical thinking skills compared to disciplines outside commerce? Most importantly: Do the critical thinking skills of commerce students actually improve following a course of study in business, as measured by well-validated pre- and post-test metrics and using experimental and control groups? Questions such as these suggest promising areas of future work. Moreover, there is the area of critical thinking and its application outside the academy, e.g. in the domain of professional practice, that needs to be further considered. Research into areas of professional practice can also shed light on how, for example, practicing accountants or marketers use critical thinking in 'on-the-ground' practical decision making, and how, and to what extent, business education and training assists in this-if indeed it does.

Some of the practice-based examples that foster critical thinking in business education that we have seen include(:) simulating how managers analyse problems, determining how managerial decision-making processes influence team members, and working out how various sources of information are used to inform commercial decisions (see Doyle 2019; Green 2019; Mendes 2019; Root 2018). These business situations can be complex and would require critical thinking. Students intending to be business analysts, accountants, managers, lawyers, marketing professionals, financial planners or trading analysts would, in most situations, evaluate data to make informed decisions particularly when acting on behalf of clients or of the company. We also anticipate with excitement the findings from the OECD project Fostering and assessing students' creative and critical thinking skills in higher education which are expected in 2021 (OECD 2018). An extension of our study would be a follow-up study to examine the different approaches in teaching and assessing critical thinking in business education. 


\section{Conclusion}

This paper used the Web of Science and Google Scholar as data sources. Consideration of other databases might have resulted in additional inclusions. It does not include editorial notes or conference abstracts. Despite these limitations, the paper provides an overview of the literature on critical thinking in business education that has not been attempted previously.

Critical thinking is increasingly seen as an important skill for business students. Our aim was to understand the conceptions of critical thinking in business education, how important they are, the contexts in which they are studied, and the topic areas being researched. We examined articles relating to critical thinking in business education-overviewing 787 articles in broad terms, and 55 mostcited articles in depth. Our contribution resulted in a synoptic outline of the literature to date, including six key areas of research. Our analysis of the literature indicates that studies in business ethics are one of the most important of these areas. However, there is a need to further develop and refine our understanding of critical thinking in business contexts as well as to expand research on its assessment and measurement. A definition of critical thinking as it applies in business education would be a useful starting point. Future research can look into empirical approaches to assessing and developing critical thinking in business education, the variety of approaches used to teach critical thinking, how business students apply it in a variety of business problems or situations, and how it is exhibited in professional practice. Specific areas of potentially fruitful research might include the application of critical thinking in various business fields other than mainstream business functions (accounting, economics, finance, management or marketing). More quantitative measures, cases and surveys to assess the development of critical thinking are also welcome.

\section{Acknowledgements}

The authors would like to acknowledge the research assistance provided by Emeline Jerez, Subodhanie Umesha Weerakkody and Nicole Ye Yang.

\section{Disclosure statement}

No potential conflict of interest was reported by the author(s).

\section{ORCID}

Angelito Calma (iD http://orcid.org/0000-0003-2456-3695

Martin Davies (D) http://orcid.org/0000-0002-5137-3638

\section{References}

AACSB. 2018. 2018 Eligibility Procedures and Accreditation Standards for Accounting Accreditation. Accessed September 25, 2019 https://www.aacsb.edu/-/media/aacsb/docs/accreditation/accounting/standards-and-tables/2018-accountingstandards.ashx?la=en\&hash=8DCDA6CE3B0CEF6AB82D39CBF53995DA96111196.

Alavi, M., B. C. Wheeler, and J. S. Valacich. 1995. “Using IT to Reengineer Business Education: An Exploratory Investigation of Collaborative Telelearning." MIS Quarterly 19 (3): 293-312. doi:10.2307/249597.

Albanese, J., and J. Paturas. 2018. "The Importance of Critical Thinking Skills in Disaster Management." Journal of Business Continuity \& Emergency Planning 11 (4): 326-34.

Allison, J. 2019. "Critical Thinking Across the Disciplines: Understanding and Application." (Doctoral thesis). University of Plymouth. https://ethos.bl.uk/OrderDetails.do?uin=uk.bl.ethos.772622.

Ayad, A. 2010. "Critical Thinking and Business Process Improvement." Journal of Management Development 29 (6): 556-64.

Bailin, S. 2002. "Critical Thinking and Science Education." Science \& Education 11 (4): 361-75. doi:10.1023/ A: 1016042608621.

Bandyopadhyay, S., and J. Szostek. 2019. "Thinking Critically About Critical Thinking: Assessing Critical Thinking of Business Students Using Multiple Measures." Journal of Education for Business 94 (4): 259-70. 
Beasley, C., and B. Cao. 2014. "Thinking Critically About Critical Thinking in the First-Year Experience." In Universities in Transition: Foregrounding Social Contexts of Knowledge in the First Year Experience, edited by H. Brook, D. Fergie, M. Maeorg, and D. Michell, 205-27. Adelaide: University of Adelaide Press.

Behar-Horenstein, L. S., and L. Niu. 2011. "Teaching Critical Thinking Skills in Higher Education: A Review of the Literature." Journal of College Teaching \& Learning 8 (2): 25-41.

Bejinaru, R. 2018. "Assessing Students' Entrepreneurial Skills Needed in the Knowledge Economy." Management \& Marketing-Challenges for the Knowledge Society 13 (3): 1119-32. doi:10.2478/mmcks-2018-0027.

Bell, R., and M. Loon. 2015. "The Impact of Critical Thinking Disposition on Learning Using Business Simulations." International Journal of Management Education 13 (2): 119-27. doi:10.1016/j.ijme.2015.01.002.

Bloch, J., and S. E. Spataro. 2014. "Cultivating Critical-Thinking Dispositions Throughout the Business Curriculum." Business and Professional Communication Quarterly 77 (3): 249-65.

Bloom, B. 1964. Taxonomy of Educational Objectives. New York: Longmans Green.

Bonk, C. J., and S. G. Smith. 1998. "Alternative Instructional Strategies for Creative and Critical Thinking in the Accounting Curriculum." Journal of Accounting Education 16 (2): 261-93. doi: 10.1016/S0748-5751(98)00012-8.

Borg, M. O., and H. A. Stranahan. 2010. "Evidence on the Relationship between Economics and Critical Thinking Skills." Contemporary Economic Policy 28 (1): 80-93.

Borthick, A. F., and G. P. Schneider. 2016. "Detecting Errors in and Making Inferences From Business Process Representations." Journal of Emerging Technologies in Accounting 13 (2): 185-94. doi:10.2308/jeta-51613.

Brook, C., and C. Milner. 2014. "Reflections on 'Creative' Action Learning in Business Education: Some Issues in its Theory and Practice." Teaching in Higher Education 19 (2): 126-37. doi:10.1080/13562517.2013.827651.

Butler, H. A., C. P. Dwyer, M. J. Hogan, A. Franco, S. F. Rivas, C. Saiz, and L. S. Almeida. 2012. "The Halpern Critical Thinking Assessment and Real-World Outcomes: Cross-National Applications." Thinking Skills and Creativity 7 (2): 112-21. doi:10. 1016/j.tsc.2012.04.00.

Carr, R., K. Evans-Locke, H. Abu-Saif, R. Boucher, and K. Douglas. 2018. "Peer-learning to Employable: Learnings From an Evaluation of PASS Attendee and Facilitator Perceptions of Employability at Western Sydney University." Journal of Peer Learning 11: 41-64.

Casey, A. J., and E. F. Goldman. 2010. "Enhancing the Ability to Think Strategically: A Learning Model." Management Learning 41 (2): 167-85.

Casner-Lotto, J., and M. W. Benner. 2006. "Are They Ready to Work? Employers' Perspectives on the Basic Knowledge and Applied Skills of New Entrants to the 21st Century US Workforce." In The Conference Board, Corporate Voices for Working Families, the Partnership for 21st Century Skills, and the Society for Human Resource Management. http:// www.p21.org/storage/documents/FINAL_REPORT_PDF09-29-06.pdf.

Celuch, K., and M. Slama. 1999. "Teaching Critical Thinking Skills for the 21st Century: An Advertising Principles Case Study." Journal of Education for Business 74 (3): 134-39. doi:10.1080/08832329909601675.

Chan, Z. C. Y. 2018. "A Systematic Review on Critical Thinking in Medical Education." International Journal of Adolescent Medicine and Health 30 (1): 1-11.

Chance, P. 1986. Thinking in the Classroom: A Survey of Programs. New York: Teachers' College, Columbia University.

Christensen, A. L., J. Cote, and C. K. Latham. 2016. "Insights Regarding the Applicability of the Defining Issues Test to Advance Ethics Research with Accounting Students: A Meta-Analytic Review." Journal of Business Ethics 133 (1): 141-63.

Cloete, M. 2018. "The Impact of an Integrated Assessment on the Critical Thinking Skills of First-Year University Students." Accounting Education 27 (5): 479-94.

Cunningham, B. M. 2014. "Developing Critical Thinking in Accounting Education." In The Routledge Companion to Accounting Education, edited by R. Wilson, 399-420. London: Routledge.

Davies, M. 2006. "An 'Infusion' Approach to Critical Thinking: Moore on the Critical Thinking Debate." Higher Education Research and Development 25 (2): 179-93.

Davies, M. 2013. "Critical Thinking and the Disciplines Reconsidered." Higher Education Research and Development 32 (4): 529-44.

Davies, M., and R. Barnett. 2015. "Introduction." In The Palgrave Handbook of Critical Thinking in Higher Education, edited by M. Davies, and R. Barnett, 12-39. New York: Palgrave Macmillan.

D'Alessio, F. A., B. E. Avolio, and V. Charles. 2020. "Studying the Impact of Critical Thinking on the Academic Performance of Executive MBA Students." Thinking Skills and Creativity 31 (2019): 275-83.

Deale, C. S. 2016. "Entrepreneurship Education in Hospitality and Tourism: Insights from Entrepreneurs." Journal of Teaching in Travel \& Tourism 16 (1): 20-39.

Dehler, G. E., M. A. Welsh, and M. W. Lewis. 2001. "Critical Pedagogy in the 'New Paradigm'." Management Learning 32 (4): 493-511. doi:10.1177/1350507601324005.

Diaz-Lefebvre, R. 2004. "Multiple Intelligences, Learning for Understanding, and Creative Assessment: Some Pieces to the Puzzle of Learning." Teachers College Record 106 (1): 49-57.

Doyle, A. 2019. "Critical Thinking Definition, Skills and Examples." Accessed December 20, 2019. https://www. thebalancecareers.com/critical-thinking-definition-with-examples-2063745. 
Dwyer, C. P., M. J. Hogan, and I. Stewart. 2014. "An Integrated Critical Thinking Framework for the 21st Century." Thinking Skills and Creativity 12 (June): 43-52.

Dyck, B. 2017. "Reflecting on 25 Years of Teaching, Researching, and Textbook Writing for Introduction to Management: An Essay with Some Lessons Learned." Journal of Management Education 41 (6): 817-34. doi:10.1177/ 1052562917693381.

Eggers, F., K. J. Lovelace, and F. Kraft. 2017. "Fostering Creativity through Critical Thinking: The Case of Business Start-up Simulations." Creativity \& Innovation Management 26 (3): 266-76. doi:10.1111/caim.12225.

Ennis, R. H. 1962. "A Concept of Critical Thinking." Harvard Educational Review 32 (1): 81-111.

Ennis, R. H. 1985. "A Logical Basis for Measuring Critical Thinking Skills.” Educational Leadership 43 (2): 44-48.

Ennis, R. H. 1987. "A Taxonomy of Critical Thinking Dispositions and Abilities." In Teaching Thinking Skills: Theory and Practice, edited by J. B. Baron, and R. J. Sternberg, 9-26. New York: W. H. Freeman and Company.

Ennis, R. H. 1989. "Critical Thinking and Subject Specificity: Clarification and Needed Research." Educational Researcher 18 (3): 4-10.

Ennis, R. H. 1996. "Critical Thinking Dispositions: Their Nature and Assessability." Informal Logic 18 (2-3): 165-82.

Ennis, R. H. 1998. "Is Critical Thinking Culturally Biased?" Teaching Philosophy 21 (1): 15-33.

Ermasova, N., S. Wagner, and L. Nguyen. 2017. "Ethics-related Organizational Interventions and Personal Business Ethics in Russia." Journal of Management Development 36 (3): 410-26.

Facione, P. 1990. The Delphi Report: Critical Thinking: A Statement of Expert Consensus for Purposes of Educational Assessment and Instruction. Millbrae: California Academic Press.

Flores, K. L., G. S. Matkin, M. E. Burbach, C. E. Quinn, and H. Harding. 2012. “Deficient Critical Thinking Skills among College Graduates: Implications for Leadership." Educational Philosophy and Theory 44 (2): 212-30.

Foundation for Young Australians. 2016. "Big Data Reveals the Skills Young People Need." Accessed October 15, 2019 https://www.fya.org.au/2016/04/20/big-data-reveals-the-skills-young-people-need/.

Foundation for Young Australians. 2017. "The New Work Smarts: Thriving in the New Work." Accessed December 20, 2019. https://www.fya.org.au/wp-content/uploads/2017/07/FYA_TheNewWorkSmarts_July2017.pdf.

Garcia, E. J. 2009. “Raising Leadership Criticality in MBAs.” Higher Education 58 (1): 113-30.

Gelder, T. V. 2005. "Teaching Critical Thinking: Some Lessons From Cognitive Science." College Teaching 53 (1): 41-48. doi:10.3200/CTCH.53.1.41-48.

Glen, R., C. Sucio, and C. Baughn. 2014. "The Need for Design Thinking in Business Schools." Academy of Management Learning and Education 13 (4): 653-67.

Google Ngram Viewer. 2019. "Critical Thinking." Accessed September 13, 2019. https://books.google.com/ngrams/graph? content $=$ critical+thinking\&year_start $=1800 \& y e a r \_e n d=2008 \&$ corpus $=15 \&$ smoothing $=3 \&$ share $=\&$ direct_url $=\mathrm{t} 1 \% 3 \mathrm{~B} \%$ 2Ccritical\%20thinking\%3B\%2Cc0\#t1\%3B\%2Ccritical\%20thinking\%3B\%2Cc0.

Green, R. 2019. "Why Critical Thinking Matters in Your Business." Accessed December 20, 2019. https://www. businessnewsdaily.com/7532-critical-thinking-in-business.html.

Griffith, W. 1999. "The Reflecting Team as an Alternative Case Teaching Model - A Narrative, Conversational Approach." Management Learning 30 (3): 343-62.

Griggs, R. A., S. L. Jackson, P. Marek, and A. N. Christopher. 1998. "Critical Thinking in Introductory Psychology Texts and Supplements." Teaching of Psychology 25 (4): 254-66.

Halpern, D. 1998. "Teaching Critical Thinking for Transfer Across Domains: Dispositions, Skills, Structure Training, and Metacognitive Monitoring." American Psychologist 53 (4): 449-55.

Halpern, D. F. 1999. "Teaching for Critical Thinking: Helping College Students Develop the Skills and Dispositions of a Critical Thinker." New Directions for Teaching \& Learning 1999 (80): 69-74. doi:10.1002/tl.8005.

Halpern, D. F. 2001. "Assessing the Effectiveness of Critical Thinking Instruction." The Journal of General Education 50 (4): 270-86. doi:10.1353/jge.2001.0024.

Halpern, D. F. 2007. "The Nature and Nurture of Critical Thinking." In Critical Thinking in Psychology, edited by R. J. Sternberg, H. L. Roediger, and D. F. Halpern, 1-14. Cambridge: Cambridge University Press.

Hummel, K., D. Pfaff, and K. Rost. 2018. "Does Economics and Business Education Wash Away Moral Judgment Competence?" Journal of Business Ethics 150 (2): 559-77.

Iqbal, M. 2019. "Harvard Business School vs. Stanford Graduate School of Business." Accessed October 7, 2019. https:// www.topmba.com/usa-canada/harvard-business-school-vs-stanford-graduate-school-business.

Johansson-Sköldberg, U., J. Woodilla, and M. Çetinkaya. 2013. "Design Thinking: Past, Present and Possible Futures." Creativity and Innovation Management 22 (2): 121-46.

Khidhir, S. 2018. "Critical Thinking Needed to Upgrade Skills". The ASEAN Post, 22/11/18. Accessed November 11, 2019. https://theaseanpost.com/article/critical-thinking-needed-upgrade-skills.

Kirby, D. A. 2004. "Entrepreneurship Education: Can Business Schools Meet the Challenge?" Education and Training 46 (8/ 9): 510-19.

Kurfiss, J. G. 1988. Critical Thinking: Theory, Research, Practice and Possibilities. Washington, DC: Association for the Study of Higher Education.

Lamb, D. 2015. "Learning About Events Through Involvement and Participation." International Journal of Event \& Festival Management 6 (1): 73-91. 
Latif, N. E. A., F. M. Yusuf, N. M. Tarmezi, S. Z. Rosly, and Z. N. Zainuddin. 2019. "The Application of Critical Thinking in Accounting Education: A Literature Review." International Journal of Higher Education 8 (3): 57-62.

Lee, H., D. Parsons, G. Kwon, J. Kim, K. Petrova, E. Jeong, and H. Ryu. 2016. "Cooperation Begins: Encouraging Critical Thinking Skills through Cooperative Reciprocity Using a Mobile Learning Game." Computers \& Education 97 (June): 97-115. doi:10.1016/j.compedu.2016.03.006.

Levant, Y., M. Coulmont, and R. Sandu. 2016. "Business Simulation as an Active Learning Activity for Developing Soft Skills." Accounting Education 25 (4): 368-95.

London Business School. 2019. "Programme Content." https://www.london.edu/masters-degrees/masters-in-financialanalysis/programme-content.

Maclagan, P. 2012. "Conflicting Obligations, Moral Dilemmas, and the Development of Judgement Through Business Ethics Education." Business Ethics: A European Review 21 (2): 183-97.

Maclagan, P., and T. Campbell. 2011. "Focusing on Individuals' Ethical Judgement in Corporate Social Responsibility Curricula. Business Ethics." A European Review 20 (4): 392-404.

Mayer, R., and F. Goodchild. 1990. The Critical Thinker. New York: Wm. C. Brown.

McEwen, B. C. 1994. "Teaching Critical Thinking Skills in Business Education." Journal of Education for Business 70 (2): $99-$ 103. doi:10.1080/08832323.1994.10117733.

McPeck, J. E. 1981. Critical Thinking and Education. New York: St Martin's Press.

McPeck, J. 1990. "Critical Thinking and Subject Specificity: A Reply to Ennis." Educational Researcher 19 (4): 10-12.

McWilliams, V., and A. Nahavandi. 2006. "Using Live Cases to Teach Ethics." Journal of Business Ethics 67 (4): 421-33.

Mendes, J. L. 2019. "Why Critical Thinking Skills are Important in the Workplace." Accessed December 20, 2019. https:// www.ziprecruiter.com/blog/why-critical-thinking-skills-are-important-in-the-workplace/.

Mingers, J. 2000. "What Is It To Be Critical? Teaching a Critical Approach to Management Undergraduates." Management Learning 31 (2): 219-37.

Mingers, J. 2015. "Helping Business Schools Engage with Real Problems: The Contribution of Critical Realism and Systems Thinking." European Journal of Operational Research 242 (1): 316-31.

Moore, T. 2004. "The Critical Thinking Debate: How General are General Thinking Skills?" Higher Education Research and Development 23 (1): 3-18.

Moore, T. 2011. "Critical Thinking and Disciplinary Thinking: A Continuing Debate." Higher Education Research and Development 30 (3): 261-74.

Moore, B., and R. Parker. 1991. Critical Thinking. 3rd ed. California: Mayfield Publishing Company.

National Association of Colleges and Employers. 2019. "The Four Career Competencies Employers Value Most." Accessed December 20, 2019. https://www.naceweb.org/career-readiness/competencies/the-four-career-competenciesemployers-value-most/.

Nentl, N., and R. Zietlow. 2008. "Using Bloom's Taxonomy to Teach Critical Thinking Skills to Business Students." College \& Undergraduate Libraries 15 (1/2): 159-72.

Organisation for Economic Co-operation and Development. 2018. "OECD Launches Research Project into Creative and Critical Thinking in HEls." Accessed December 12, 2019. https://heinnovate.eu/en/news/oecd-launches-researchproject-creative-and-critical-thinking-heis.

Organisation for Economic Co-operation and Development. 2019. "OECD Future of Education and Skills 2030." Accessed December 12, 2019. http://www.oecd.org.ezp.lib.unimelb.edu.au/education/2030-project/teaching-and-learning/ learning/transformative-competencies/Transformative_Competencies_for_2030_concept_note.pdf.

Page, D., and A. Mukherjee. 2007. "Promoting Critical-Thinking Skills by Using Negotiation Exercises." Journal of Education for Business 82 (5): 251-57.

Paul, R. W. 1993. Critical Thinking: What Every Person Needs to Survive in a Rapidly Changing World. Santa Rosa, CA: Foundation for Critical Thinking.

Peach, B. E., A. Mukherjee, and M. Hornyak. 2007. "Assessing Critical Thinking: A College's Journey and Lessons Learned." Journal of Education for Business 82 (6): 313-20. doi:10.3200/JOEB.82.6.313-320.

Prince, M. 2004. "Does Active Learning Work? A Review of the Research." Journal of Engineering Education 93 (3): $223-31$. doi:10.1002/j.2168-9830.2004.tb00809.x.

QSR International. 2019. "What is NVivo." Accessed October 10, 2019. https://www.qsrinternational.com/nvivo/what-isnvivo.

Quigley, N. R. 2013. "A Longitudinal, Multilevel Study of Leadership Efficacy Development in MBA Teams." Academy of Management Learning \& Education 12 (4): 579-602.

Reale, M. C., D. M. Riche, B. A. Witt, W. L. Baker, and M. J. Peeters. 2018. "Development of Critical Thinking in Health Professions Education: A Meta-Analysis of Longitudinal Studies." Currents in Pharmacy Teaching \& Learning 10 (7): 826-33.

Reeves, M. F. 1990. "An Application of Bloom's Taxonomy to the Teaching of Business Ethics." Journal of Business Ethics 9 (7): 609-16.

Rezaei, S., L.-P. Dana, and V. Ramadani. 2017. Iranian Entrepreneurship: Deciphering the Entrepreneurial Ecosystem in Iran and in the Iranian Diaspora. Cham: Springer.

Richards, W. 2018. “Facing Difficult Questions: Public Outreach Starts with Education.” Architect 107 (6): 151. 
Root, D. 2018. "How to Promote Critical Thinking in the Workplace." Accessed December 20, 2019. https://www. eaglesflight.com/blog/how-to-promote-critical-thinking-in-the-workplace.

Roy, A., and B. Macchiette. 2005. "Debating the Issues: A Tool for Augmenting Critical Thinking Skills of Marketing Students." Journal of Marketing Education 27 (3): 264-76. doi:10.1177/0273475305280533.

Seldomridge, L. A., and C. M. Walsh. 2006. "Measuring Critical Thinking in Graduate Education: What Do We Know?" Nurse Educator 31 (3): 132-37.

Sellars, M., R. Fakirmohammad, L. Bui, J. Fishetti, S. Niyosov, R. Reynolds, N. Thapliyal, Y. Smith, and N. Ali. 2018. "Conversations on Critical Thinking: Can Critical Thinking Find Its Way Forward as the Skill Set and Mindset of the Century?" Education Sciences 8 (205): 1-29.

Shakirova, D. M. 2007. "Technology for the Shaping of College Students' and Upper-Grade Students' Critical Thinking." Russian Education and Society 49 (9): 42-52.

Sharma, E., and S. Sharma. 2018. "Creativity Nurturing Behaviour Scale for Teachers." International Journal of Educational Management 32 (6): 1016-28.

Smith, G. F. 2003. "Beyond Critical Thinking and Decision Making: Teaching Business Students how to Think." Journal of Management Education 27 (1): 24-51.

Snyder, L. G., and M. J. Snyder. 2008. "Teaching Critical Thinking and Problem Solving Skills." Delta Pi Epsilon Journal 50 (2): 90-99.

Sormunen, C., and M. Chalupa. 1994. "Critical Thinking Skills Research: Developing Evaluation Techniques." Journal of Education for Business 69 (3): 172-77.

Springer, C. W., and A. F. Borthick. 2004. "Business Simulation to Stage Critical Thinking in Introductory Accounting: Rationale, Design, and Implementation." Issues in Accounting Education 19 (3): 277-303.

Turner, Y. 2005. "Students From Mainland China and Critical Thinking in Postgraduate Business and Management Degrees: Teasing out Tensions of Culture, Style and Substance." International Journal Of Management Education 5 (1): 3-12.

Verzat, C., N. O'Shea, and M. Jore. 2017. "Teaching Proactivity in the Entrepreneurial Classroom." Entrepreneurship \& Regional Development 29 (9-10): 975-1013.

von der Heidt, T. 2018. "A Scholarship Approach to Embedding Creativity and Sustainability in Marketing Principles Curriculum." Australasian Marketing Journal 26 (2): 99-115.

Watson, G. B., and E. M. Glaser. 1994. Watson-Glaser Critical Thinking Appraisal, Short Form. Edited by Kurt F. Geisinger and Stephen H. Ivens, January. San Antonio, TX: Pearson.

Wilkin, C. L. 2017. "Enhancing Critical Thinking: Accounting Students' Perceptions." Education + Training 59 (1): 15-30. doi:10.1108/ET-01-2015-0007.

Willingham, D. T. 2008. "Critical Thinking: Why is it so Hard to Teach?" Arts Education Policy Review 109 (4): 21-32.

Wolcott, S. K., C. P. Baril, B. M. Cunningham, D. R. Fordham, and K. St. Pierre. 2002. "Critical Thought on Critical Thinking Research." Journal of Accounting Education 20 (2): 85-103.

Wong, D. 2007. "Beyond Control and Rationality: Dewey, Aesthetics, Motivation, and Educative Experiences." Teachers College Record 109 (1): 192-220.

Wright, R. P., S. E. Paroutis, and D. P. Blettner. 2013. "How Useful Are the Strategic Tools We Teach in Business Schools?" Journal Of Management Studies 50 (1): 92-125.

Zabit, M. N. M. 2010. "Problem-based Learning on Students' Critical Thinking Skills in Teaching Business Education in Malaysia: A Literature Review." American Journal of Business Education 3 (6): 19-32.

Zayapragassarazan, Z., V. Menon, S. S. Kar, and G. Batmanabane. 2016. “Understanding Critical Thinking to Create Better Doctors." Journal of Advances in Medical Education and Research 1 (3): 9-13. 